\title{
MANDADO DE SEGURANÇA - EXAME DE PROVAS - PROCESSO
}

\section{DISCIPLINAR}

l. Nāo cabe reexaminar em mandado de segurança os elementos de provas e os concernentes à materialidade e autoria do delito, porque exigem instrução probatória.

2. A ausência de decisão judicial com trânsito em julgado não torna nulo o ato demissório aplicado com base em processo administrativo em que foi assegurada ampla defesa, pois a aplicação da pena disciplinar ou administrativa independe da conclusão dos processos civil e penal, eventualmente instaurados em razão dos mesmos fatos. 
Interpretação dos artigos 125 da Lei n" 8.112/90 e 20 da Lei n" 8.429/92 em face do artigo $41, \S I^{\circ}$. da Constituiçāo. Precedentes.

3. Mandado de segurança conhecido, mas indeferido, ressalvando-se ao impetrante as vias ordinárias.

\title{
SUPREMO TRIBUNAL FEDERAL \\ Mandado de Segurança n" 22.534
}

\author{
Impetrante: Lucinerges Teles da Rosa \\ Impetrado: Presidente da República \\ Relator: Sr. Ministro MAURÍCIO CORRÊA
}

\section{ACÓRDÃO}

Vistos, relatados e discutidos estes autos, acordam Ministros do Supremo Tribunal Federal, em Sessão Plenária, conformidade da ata do julgamento e das notas taquigráficas, unanimidade de votos, indeferir o pedido de mandado de segurança.

Brasília, 19 de maio de 1999.

CELSO DE MELLO - PRESIDENTE MAURÍCIO CORRÊA - RELATOR

\section{RELATÓRIO}

O SENHOR MINISTRO MAURÍCIO CORREA: Trata-se de mandado de segurança impetrado em 21.03.96, em que o impetrante afirma que teve direito líquido e certo violado por ato do Presidente da República, praticado ao demiti-lo do cargo de Agente de Polícia Federal, do Departamento de Polícia Federal, do Ministério da Justiça, por decreto de 25.04.96, publicado no DOU de 24.04.96, fundado nas conclusões do Processo Administrativo no 08200.001817/95-11 (fls. 13/14).

Alega, em síntese, que não estava transportando a mercadoria contrabandeada, mas conduzindo o contrabandista e os bens apreendidos para Foz do Iguaçu quando foi preso em flagrante delito, e que embora reconhecendo não caber reexame de provas em mandado de segurança, " a decisão proferida no processo administrativo decorreu de equivocada valoração do conjunto provatório"; aduz também que o desfecho do processo administrativo deveria aguardar o trânsito em julgado do processo-crime que está em curso, porque têm o mesmo objeto.

Pede a suspensão do ato impugnado até a decisāo final do processo-crime (fls. 2/11). Junta documentos (fls. 12/21).

2. Não deferi o pedido cautelar (fls. 24 e $37)$.

3. Vêm aos autos as informaçōes prestadas pelo impetrado, contrariando a pretensão deduzida na inicial (fls. 29/36).

4. Manifesta-se o Procurador-Geral da República, Dr. Geraldo Brindeiro, aprovando parecer do Subprocurador-Geral da República Flávio Giron, em que opina pelo indeferimento do writ em parecer assim ementado, verbis (fls. 39/41):

"Mandado de Segurança. Servidor Público. Demissão. Infração disciplinar apurada em procedimento administrativo precessor à decisão do Juizo Criminal que trata do mesmo fato. Requerida sustaçāo, até o julgamento final da açāo penal, do ato demissório expedido pelo Presidente da República. $O$ processo administrativo disciplinar, independe da conclusão do processo criminal a que foi submetido o servidor, por crime contra a Administração Pública. Precedentes do STF. Parecer pelo indeferimento do writ." É o relatório. 


\section{VOTO}

O SENHOR MINISTRO MAURÍCIO CORREA (Relator): Senhor Presidente, excluo a apreciação do reexame dos elementos de prova e as concernentes à autoria e materialidade do ilícito, que não podem ser examinadas em mandado de segurança porque exigem instrução probatória.

2. Nāo procede a alegação de indevida perda da função pública antes do trânsito em julgado de sentença penal condenatória, embora haja notícia nos autos de que a ação penal foi instaurada, porque o artigo 20 da Lei $n^{\mathcal{Q}}$ $8.429 / 92$ (a perda da função pública e a suspensão dos direitos políticos só se efetivam com o trânsito em julgado da sentença condenatória) e o artigo 125 da Lei $n^{2} 8.112 / 90$ (a responsabilidade administrativa do servidor será afastada no caso de absolvição criminal que negue a existência do fato ou sua autoria) devem ser interpretados em consonância com o artigo $41, \S 1^{2}$, da Constituição, segundo o qual o servidor público estável só perderá o cargo em virtude de sentença judicial transitada em julgado ou mediante processo administrativo em que lhe seja assegurada ampla defesa.

Com efeito a ordem jurídica vigente estabelece a independência das instâncias administrativa. civil e penal, nāo importando, pois, que o mesmo fato constitua ilícito penal e administrativo para efeito de aplicação das respectivas sançōes cumulativamente. Ressalva-se, é certo, que a decisão penal pode influir na esfera administrativa se restar provada a negativa da autoria ou da materialidade do fasto, casos em que não se concebe punição. Mas isto não quer dizer que a Administração é obrigada a aguardar o desfecho do processo penal; deve assegurar ao servidor, apenas, a garantia de ampla defesa no processo administrativo.

Neste sentido é a antiga, unânime e reiterada jurisprudência deste Tribunal, como se vê no MS n² 21.705-SC, j. em 16.11.95 unânime. da minha relatoria, in RTJ 159/806, assim ementado nesta parte, verbis:

"Mandado de segurança. Servidor Público

- Demissão após processo administrativo disciplinar. Le galidade da demissão. Aplicafăo do artigo 4l. \$ $1^{\circ}$, da Constituiçâo Fede$\mathrm{ral}$ c/c artigo $132, I, I V, X$ e XI, da Lei $n^{2}$ $8.1 / 2 / 90$.

4. A ausência de decisão judicial com trânsito em julgado não torna nulo o ato demis. sório, pois a aplicação da pena disciplinar ou administrativa independe da conclusāo dos processos civis e penais, eventualmente instaurados em razāo dos mesmos fatos."

No mesmo sentido: RE ne 75.421-BA, j. em 29.10.74, unânime, Rel. Min. OSWALDO TRIGUEIRO; RE $\mathrm{n}^{\mathrm{Q}}$ 136.905-SP, j. em 08.09.94, unânime, Rel. Min. CARLOS VELLOSO; MS n 16.404-DF, j. em 31.08.66, unânime, Rel. Min. LUIZ GALLOTTI; in RTJ 41/598; MS n² 20.947-DF, j. em 19.10.89, unânime, Rel. Min. PAULO BROSSARD, in DJU de 10.11.89; MS $\mathrm{n}^{2}$ 20.948-DF, j. em 12.10.89, unânime, Rel. Min. FRANCISCO REZEK; in RTJ 130/110; MS n 21.254-DF, j. em 06.06.91, unânime, Rel. Min. OCTAVIO GALLOTTI, in DJU de 02.08.91; MS n² 21.294-DF, j. em 23.10.91, maioria, Rel. Min. SEPÚLVEDA PERTEN$\mathrm{CE}$, acórdāo ainda nāo publicado; $\mathrm{MS} \mathrm{n}^{\mathrm{Q}}$ 21.301-DF, j. em 04.08.93, unânime, Rel. Min. ILMAR GALVÃO, in RTJ 149/99; MS $\mathrm{n}^{2}$ 21.332-DF, j. em 27.11.92, unânime, in DJU de 07.05.93, $e$ MS n 21.948-RJ, j. em 29.09.94, unânime, in DJU de 07.12.95, ambos relatados pelo Min NÉRI DA SILVEIRA; etc.

5. Ante o exposto, constada a inexistência de direito líquido e certo violado e acolhendo o parecer do Ministério Público Federal, conheço do pedido, mas indefiro a segurança, ressalvando a impetrante, caso queira, que recorra às vias ordinárias.

\section{EXTRATO DE ATA}

MANDADO DE SEGURANÇA № 22.534-3

Proced.: Paraná

Relator: Min. Maurício Corrêa

Impte.: Lucinerges Teles da Rosa

Adv:: Pedro de Assis 
Impde.: Presidente da República Decisão: O Tribunal, por votação unânime, indeferiu o pedido de mandado de segurança, ressalvando, no entanto, ao impetrante, o acesso às vias ordinárias. Ausentes, justificadamente. os Ministros Moreira Alves, Carlos Velloso, Ilmar Galvão e Nelson Jobim. Plenário, 19.5.99. 